\title{
Power and conflict in macropolicy-making: a note on a political economy of an incomes policy
}

Poder e conflito na elaboração de macropolíticas: uma nota sobre uma economia política de renda

GILBERTO TADEU LIMA*,**

RESUMO: É apresentada uma breve e tentativa análise de alguns aspectos da economia política de renda baseada em impostos, com base em algumas contribuições da microeconomia política e da macroeconomia política. A atenção primária é dada a algumas exigências políticas e institucionais a serem cumpridas por tais políticas, enquanto as questões técnicas problemáticas são tratadas apenas na medida em que elas atinjam esses requisitos.

PALAVRAS-CHAVE: Poder; conflito; política de rendas.

ABSTRACT: It is presented a brief and tentative analysis of some political economy aspects of a tax-based incomes policy by building on some contributions from the political microeconomy and the political macroeconomy. Primary attention is paid to some political and institutional requirements to be met by such policies, while troublesome technical issues are dealt with only to the extent that they have a bear- ing on those requirements.

KEYWORDS: Power; conflict; incomes policy.

JEL Classification: E64.

\section{INTRODUCTION}

This short paper is devoted to a tentative analysis of some political economy aspects of incomes policies by building on some elaborations developed in the literature on political microeconomy and political macroeconomy. I should add that primary attention will be paid to some political and institutional requirements to be met by such policies, troublesome technical issues being dealt with only to the extent

\footnotetext{
* Assistant Professor, Departamento de Economia, Universidade de São Paulo - USP, São Paulo/SP, Brasil, e-mail: giltadeu@usp.br. Submitted: March 2003; accepted: December 2003.

* * I should thank, without implicating, two anonymous referees for comments. Also, research funding from the Brazilian National Council of Scientific and Technological Development (CNPq) should be grate- fully acknowledged.
} 
that they have a bearing on those requirements. Even though the technical literature on incomes policies is enormous, the analysis that follows is predicated upon the belief that a deeper understanding about their potential effectiveness requires that they be approached from a political economy standpoint as well. Besides, I focus upon the basic features of a specific kind of incomes policy, the so-called 'tax-based incomes policy', though occasional attempts at evaluating to what extent a given conclusion also holds for incomes policies in general are carried out as well.

\section{EARLY ELABORATION OF A TAX-BASED INCOMES POLICY}

The considerations that led Sidney Weintraub and Henry Wallich (1971, hereafter WW), at first independently, and then in collaboration, to propose the socalled tax-based incomes policy (hereafter TIP) in the early 1970s — as a potential supplement to conventional fiscal and monetary approaches to curbing price inflation - are the following. ${ }^{1}$ First, they saw inflation as being a matter of keen social concern, even at the relatively modest rates experienced during the 1950s and well before the dramatic acceleration of inflation that occurred during the 1970s. Second, they believed that the containment of inflation necessarily involves consideration of economic policy, their innovative proposal representing an alternative to the policy prescriptions of conventional theory and challenging the profession to search for original policies to deal with inflation. Third, they recognised that solutions to the inflation problem could not be evaluated independently of the social goal of the maintenance of full employment. In their view, the twin goals of price level stability and full employment had so far eluded conventional monetary and fiscal techniques, so that new measures were required to counter the experience of 1969-1970, when unemployment and prices rose simultaneously in contrast to past business cycles when their paths diverged.

Rather than regard an incomes policy as a substitute for monetary and fiscal policy, the proposal delivered by WW was seen as a supplement to those instruments, so that the economy might operate closer to full employment without the inflationary danger of excess demand or overheating. An incomes policy in a wageinduced inflation involves mainly a redirection of the traditional emphasis, for the conventional view argued that to control inflation aggregate demand had to be reduced, and that the ensuing recession would dampen wage and price increases. In contrast to such a view, the proposal delivered by WW was intended to suggest a

\footnotetext{
${ }^{1}$ Previous independent works on this issue by the authors were originally linked by Leonard Silk in articles in the New York Times, 1970. Earlier writings include: by Henry Wallich, Newsweek, September 5, 1966, December 14, 1970; and New York Times, December 16, 1970. On the part of Sidney Weintraub, "An incomes policy to stop inflation”, Lloyds Bank Review, January 1970, and a truncated statement on "A proposal to halt the spiral of wages and prices", New York Times, 1970.
} 
direct attack on inflation with a view to improve the short run trade-off between inflation and unemployment. Finally, as they understood that the organisation of the U.S. economy relies heavily on freely functioning markets for the allocation of resources among competing uses, they argued that stabilization policies with the greatest probability of success in containing inflation must be designed to minimise interference with the functioning of the market mechanism. In this context, the basic feature of their proposal is that, instead of disrupting the market processes, it relies upon market forces, leaving business and labour free to make their own decisions.

The underlying principle of TIP is that by imposing a tax on the profits of firms granting wage increases in excess of some guidepost figure, the behaviour of both firms and workers could be modified in such a way as to reduce inflationary pressures in the aggregate. Unlike direct controls, TIP was therefore intended to maintain the flexibility of wages and prices, which is necessary for efficient allocation of resources in a market economy. If the wage guidepost were 5.5 percent, and a wage increase of 7 percent were granted, the corporate profits tax for the firm would rise by some multiple of the 1.5 percent excess. For WW, the added tax burden may be expected to stiffen the company's back in wage negotiations, and the result would be a lower rate of wage increases, and a slowing of the rate of inflation. The tax surcharge, it is important to note, is a tax on the income of the corporation, and not on either the excess payroll or the excess labour income. Note that the proposal is asymmetrical in character, for the tax is levied on and paid by the corporation, while it is the advance of wages that is to be restrained. ${ }^{2}$

Thus, even though one could well argue that the proposal is broadly evenhanded, WW reply that this claim needs to be supported by more detailed consideration. To the extent that most varieties of incomes policy address themselves to both wages and prices - or to wages, prices and profits - WW recognised that one could argue that under the present proposal, prices, too, should be controlled in some form. The reason why this is not done, WW sustain, is that the average markup of prices over unit labour costs has been remarkably constant. If prices are in this form tied to wages, restraint on wage increases implies restraint on price increases, so that no separate control of prices is required. Moreover, WW argued that the corporation paying the surcharge would be unlikely to be able to shift it to the consumer in the form of higher prices, this being so for reasons to be detailed below. In this context, WW argued that the effect of a proposal for a surtax on profits is similar to that of a price freeze unaccompanied by a wage freeze. If firms were not

\footnotetext{
${ }^{2}$ As cogently reminded by one of the referees, however, intersectoral capital reallocations due to changes in after-tax relative profits could eventually end up putting a further upward pressure on prices. More broadly, the remind is for one to wonder whether TIP proponents paid enough attention to general equilibrium effects as opposed to partial equilibrium ones, an issue which will somehow surface in the analysis developed towards the end of this paper.
} 
allowed to raise prices, wage increases would eat directly into profits, and management's resistance to wage increases would be stiffened, precisely the same effect being achieved under the TIP. However, the harmful effects and administrative difficulties of a price freeze would be avoided.

WW also recognise that it might be argued that, if excessive wage demands on the part of workers are largely responsible for inflation, a penalty tax should be levied on the income of labour rather than of the corporation. This could be done by means of a payroll tax, or by making excess wage increases non-deductible for income tax purposes, or by taxing labour income directly. In their view, none of these techniques would achieve the objective of restraining the corporation in the granting of wage increases, the reason being that a wage tax or any similar tax can easily be shifted by the corporation. As regards a payroll tax, which represents a direct increase in costs, this is obvious, and disallowance of the dollar amount of an excess wage increase for income tax purposes has the same effect of raising costs. A tax on labour income, in turn, very likely would be included by labour in its wage demands and would thus be translated into an increase in costs. A tax on the income of a corporation, on the other hand, is very much less likely to be shifted, both economic theory and empirical research seeming to confirm this, especially with respect to short run tax changes. As far as the distributional effects of TIP are concerned, WW argued that nothing in the proposal is likely to alter the prevailing income distribution, for as the intention is only to hold wage gains (nearly) equal to average productivity improvement, the wage share would tend to be maintained.

As regards the setting of the guidepost, WW suggested that wage increases should be governed by nationwide productivity gains and not by the gains of a firm or an industry. Equal wage increases throughout the economy, for comparable types of labour, would be the rule if labour markets were fully competitive, in the sense that there would be no wage differentials on account of different productivity gains, and else labour would move out the low gaining industries into the high gaining industries. For WW, the guidepost simply seeks to reach by rule what in a competitive labour market would happen automatically.

In terms of allocative shifts in the capital-labour resource use that might be induced by TIP, WW admitted that it would be likely to create an inducement to reduce the average level of skill of the labour force due to its inducement to reduce the average wage. They argued that this phenomenon, should it develop, would not necessarily detract from the proposal, the reason being that a cut in costs, tending to reduce prices, should be welcome. As lower-priced employees are demanded, and their wages thereby lifted most rapidly, some damping of the shift-over will occur. Any tendency of the tax to encourage the use of less costly labour would contribute toward greater income equality, thus easing social tensions. Besides, such a decrease in the demand for highly skilled labour would not imply a reduction in the aggregate demand for labour. Rather, the overall effect of a successful incomes 
policy like TIP would be to make possible higher employment without increasing price inflation.

In sum, WW believed that TIP would be able to make an important contribution to checking inflation, especially because it is less of a departure from reliance on free markets. In their view, going beyond monetary and fiscal restraint to a TIP is less of a wrench than going to some form of direct intervention in wage and price setting. But they admitted that since the enactment of TIP would take time, perhaps about one year, it may be necessary to move provisionally to another form of incomes policy that could check inflation almost instantly. Even then, though, TIP deserves consideration as a long run solution. For WW, one of the clearly demonstrated features of other forms of incomes policy is that, in the case they are effective initially; they tend to break apart in the course of time. The effectiveness of TIP, in turn, should improve over time as administrative techniques are perfected and the market learns to respond to it.

\section{FURTHER ELABORATIONS ON INCOMES POLICIES}

In turn, Layard (1982) argued that only a permanent incomes policy can substantially reduce the non-inflationary unemployment level. For Layard, conventional incomes policy, which permanently suspended collective bargaining, would be out of the question in a free society, so that we have to have an incomes policy that works by incentive rather than by regulation. Like WW, he argued that the best thing would be a tax on wage increases, levied on employers and proportional to wage increases above a prescribed norm.

Layard distinguishes between the case for a policy designed to reduce inflation (which could be a temporary policy) and one designed to hold inflation steady (which would presumably be permanent), and suggests some requirements of an incomes policy. The first is permanence without prohibiting the free bargaining of wages between employers and workers. The second is that it should not take away from workers any part of their gross pay, otherwise it would face strong political opposition and would soon be dropped. The third is that the tax should be based on the money that employers actually pay out and not on the notional value of settlements. Lastly, it should be neutral in distributive terms, for income distribution should be dealt with through taxes and transfers and not through pay policy.

Having set out these requirements, Layard presents a proposal that is similar to that presented by WW. Each year the government would declare a norm for the rate of growth of hourly earnings. If an employer increased his average hourly earnings by more than this, all his excess payments would be subject to a given tax; likewise, she could be rewarded for payment below the norm. For Layard, the tax would have nothing to do with the pay of an individual, but only with the average hourly earnings at the firm level. To avoid that such a policy increase the aggregate 
net tax burden on companies, Layard suggested that in each period social security contributions should be reduced (or rebated) by an amount that would in aggregate just offset the tax proceeds from the wage-inflation tax. This rebate would be proportional to the firm's wage-bill, while the tax was proportional to its excess wage-bill. ${ }^{3}$

Another extension of the original TIP was put forward by Wallich \& Stockton (1989, hereafter WS), their purpose being to incorporate two important macroeconomic channels that became apparent from the inflation experience of the 1970s. First, the importance of curbing the psychology of inflation is considered, their position being that the influence of TIP on inflation expectations, particularly when coordinated with a credible monetary policy aimed at steady reduction in rates of price inflation, can actually reduce the considerable costs of disinflation. Secondly, the puzzling productivity slowdown experienced in the 1970s, which exacerbated the dilemmas of policymakers in reducing inflation, is considered.

For WS, TIP can be used to lower the rate of unemployment compatible with stable inflation in circumstances when a reduction in the rate of growth of productivity requires slower growth of real wages. In their view, there are several reasons to expect that the outcome of bargaining in labour markets, in the absence of TIP, would be slower to reflect changing growth in productivity. First, while firms will recognise increasing costs almost immediately, the source of rising unit costs is likely to be less clear. The initial effect on the firm would be a squeeze on profitability, probably followed by some increase in price.

As a result, the initial effect of a productivity slowdown would be a rise in inflation, and an upward surge in inflation would be prevented only if firms granted smaller wage increases to their workers on the justification that the squeeze on their profitability requires a reduction in costs. Workers, on the other hand, would be reluctant to acquiesce to the lower wage offers of firms, for the rather nebulous cause of the productivity slowdown, which remains a puzzle to economists, is not likely to be any clearer to workers. Furthermore, there is a problem of moral hazard involved in the firms persuading workers that productivity has actually slowed, the reason being that workers recognise that firms have an interest in distorting or exaggerating claims of lower productivity in order to lower labour costs and boost profitability. In addition, if workers believe that productivity has declined in their firm but not in the aggregate, they might well be reluctant to reduce wages and suffer what would be viewed as a relative wage reduction.

For WS, a TIP can alleviate some of the conflict or inflation that will arise in such circumstances. By averaging over the entire economy, an overall slowdown in productivity can be disentangled from firmor industry-specific problems. Since TIP

\footnotetext{
${ }^{3}$ As correctly pointed out by one of the referees, one should wonder whether Layard's proposal works for sectors whose productivity growth is above the average as well as it seems to work, at least partially, for sectors whose productivity growth is below the average, though.
} 
would be applied on a broad scale in the labour markets, uniformity should make workers less resistant to the slower growth in real wages that would be consistent with price stability. Moreover, the flexibility of TIP allows those firms and industries with high growth in productivity to raise relative wages, albeit at some penalty, and attract the labour needed to expand production. ${ }^{4}$

\section{A BRIEF POLITICAL ECONOMY EXAMINATION}

Having outlined the basic features of a TIP, I now build on some political economy elaborations to set forth a tentative analysis of some of those features. I should mention that what follows is predicated upon Schott's (1984) notion that the power distribution in society and how conflict is mediated is an important issue for political economists to consider when analyzing economic policy.

As regards the contention that some TIP is a necessary requisite for the economy to operate closer to full employment without the inflationary danger of overheat capitalism central to the perpetuation of its institutional structure (Kalecki, 1943; Boddy \& Crotty, 1975). ${ }^{5}$ Moreover, TIP overlooked the fact that the production process is first and foremost a locus of extraction of labour from labour power, Bowles' (1985) labour extraction model being a revealing illustration of the way unemployment is likely to emerge from the conflict of interest between employers and workers over work effort. ${ }^{6}$ It is not surprising that TIP, by overlooking this dimension of wage determination, ultimately conceives labour market exchanges as

\footnotetext{
${ }^{4}$ Admittedly, the extent to which wage bargaining is (de)centralized has a great bearing on the issue of the practical difficulties involved in the implementation of a TIP. Indeed, it seems reasonable to suggest that those difficulties - and some of the conflict-exacerbating features of a TIP which will surface in the next section - would rise with the degree of decentralization of wage bargaining.

${ }^{5}$ Indeed, Kalecki (1943) is a classic attempt to explain and interpret short run macropolicy and the recurrent phenomenon of the business cycle in terms of their class origins and implications. For Kalecki, the assumption that a government will maintain full employment in a capitalist economy if it only knows how to do it is fallacious, given the misgivings of big business about it - which are due to the dislike of i) government interference in the problem of employment as such, ii) the direction of government spending, and iii) the social and political changes resulting from the maintenance of full employment, for in such a case unemployment would cease to play its role as a disciplinary device. Empirical evidence in support of Kalecki's view is provided by Boddy \& Crotty (1975), where US economy data for the period 194772 is employed to illustrate how capital will usually attempt to manipulate the business cycle to discipline labour and reduce wage costs in the interests of corporate profit maximization.

${ }^{6}$ Bowles' marxian analysis is predicated upon the view that due consideration of the ownership of the means of production, and the command over the production process which this ownership permits, is essential to a coherent analysis of the production process itself, and to the analysis of market equilibration and competition. For Bowles, given a positive cost of surveillance and a conflict of interest between employers and workers over work effort, the wage rate offered by the profit-maximizing employer will exceed the worker's next best alternative, such a discrepancy being possible in general only if the probability of reemployment is less than one, so that labour market competition cannot clear the labour market.
} 
political problems that can be solved through the fully impartial intervention of an autonomous state in charge of establishing a given guidepost for wage increases.

Bowles \& Gintis (1990), in turn, challenged the traditional walrasian assumption that conflicts of interest in the economy are resolved in contracts that are either voluntarily observed or are enforceable at no cost to the exchanging parties, an economic transaction being nothing but a solved political problem. They argue that exchanges may be solved political problems where contracts are comprehensive and enforceable at no cost to the exchanging parties, such an exogenous claim enforcement tending to occur only where the transaction is transparent. Where some aspect of the object of exchange is so complex or difficult to monitor that comprehensive contracts are not feasible or enforceable by a third party, however, exogenous claim enforcement does not obtain, and the exchange in question is not a solved political problem.

As a consequence, a problem of agency arises, in the sense that one of the parties can take actions that are harmful or beneficial to the other party's interest, and which cannot be either precluded or guaranteed by contractual agreement. Where such a problem exists, the de facto terms of an exchange result in part from the sanctions, surveillance, and other enforcement activities adopted by the parties themselves, in a process that they refer to as one of endogenous claim enforcement. And a transaction characterized by both an agency problem and endogenous claim enforcement is what they termed a contested exchange.

At this juncture, an important lesson to be drawn from this contribution by Bowles and Gintis is that an effective incomes policy must necessarily be predicated upon the contestable nature of labour market exchanges, a crucial issue here being how to minimize the potential inflationary impact of endogenously enforced labour market contracts. Indeed, it is my contention that such an issue is just an aspect of a broader one: to what extent, if any at all, incomes policies can foster cooperation in contractual processes of endogenous claim enforcement.

It might be argued, in turn, that a detailed analysis of the feasibility conditions to be met by TIP in a market economy should begin with an adequate understanding of both which state is being dealt with and which institutional functions is it capable to perform. In my view, underlying TIP seems to be a naive view of the nature of the state and the exercise of state power. Indeed, the state is seen not as a complex system of political domination that ultimately configurates a form of power. Rather, underlying TIP seems to be a view of the state inspired by an economic policy model in which no heed is paid to factors such as the power distribution in society or the complex political arrangements that influence economic policy formation. In fact, TIP proponents seemed to treat the state as nothing but a neutral referee that pursues and controls economic policy.

To put it another way, TIP proponents seemed to believe that the political processes which generate monetary and fiscal decisions are unbiased and exclusively concerned with the public interest, the same being true for the process leading to 
the definition of guideposts for wage increases. In turn, since underlying TIP is a view of the state that overlooks the notion that the adequacy of particular policy instruments and general forms of intervention will vary not only with changes in economic structure but principally with changes in the balance of political forces itself, it is not surprising that their proponents believed that nothing in the proposal is likely to alter the prevailing distribution of income. However technically desirable such neutrality might be, and this is a question that goes beyond the scope of this short paper, I would only venture that the very notion of a neutral - from the distributional standpoint - incomes policy is a contradiction in terms.

As I put it earlier, the view that the government will maintain full employment in a market economy if it only knows how to do it is fallacious, for under a market system the level of output and employment depends to a great extent on the private state of confidence. Unsurprisingly, this situation gives to capitalists a powerful indirect control over government policy, so that once the government learns the trick of increasing employment by its own, this powerful device loses effectiveness (Kalecki, 1943). In this context, I would venture that an interesting question that arises regards the extent to which, if any at all, inflation can also be seen as a worker and government discipline device. Indeed, one might well wonder to what extent inflation itself generates some rents to capitalists. If it does, the feasibility of a TIP will be greatly reduced, for once the government learns the trick of curbing inflation almost by its own, that disciplinary device loses effectiveness. In this case, capitalists would have a strong disincentive to endorse TIP, thus greatly undermining its feasibility conditions.

Besides, capitalists' resistance is likely to be considerably increased by their fear of ex post opportunistic behaviour on the part of government in the appropriation of the rents created by price stabilily. As regards Layard's (1982) suggestion that an employer should be rewarded for payment below the norm for the growth rate of hourly earnings, one might well contend that it is likely to exacerbate, rather than alleviate, the conflictual nature of wage bargaining, as workers are expected to resist to it. Indeed, the overall effect of an incomes policies along the lines suggested by TIP proponents might lead to be an exacerbation of a conflict that is endemic in the capitalist system (Rowthorn, 1977), the primary reason being that TIP, instead of creating potential arenas for cooperation, actually creates another arena for competition leading to conflict.

The effectiveness of an incomes policy seems to depend crucially on the existence of a social structure of stabilization that guarantees not only the curbing of the inflationary process, but also that price stability be maintained through time. Indeed, as the experience of some chronically inflationary countries demonstrates, the effectiveness of an incomes policy is dependent not only on an antiinflationary package that curbs inflation in the first place, but mainly on the creation of an institutional environment that leaves no room for ex post opportunistic behaviour on the part of the parties involved. Though price stability itself contributes to the 
consolidation of that environment, it may not suffice, thus making a case for the imperative of a more permanent incomes policy. The question may not be whether some post-stabilization incomes policy is necessary, but how to make it institutionally compatible with the distribution of power and political arrangements.

Indeed, one might well argue that the crucial problem posed for a democratic state trying to engender both the creation and the institutional amalgamation of a social structure of stabilization - in a system where the working class has become more powerful over the past century - is how to mediate cooperative incomes policies compatible with the balances of power in society.

\section{REFERENCES}

BODDY, R. \& CROTTY, J. (1975). "Class conflict and macropolicy: the political business cycle". Review of Radical Political Economy, 7.

BOWLES, S. (1985). "Production process in a competitive economy: Walrasian, neo-Hobbesian, and Marxian models". American Economic Review, March.

BOWLES, S. \& GINTIS, H. (1990). “Contested exchange: new microfoundations for the political economy of capitalism". Politics and Society, 18(2).

KALECKI, M. (1943). "Political aspects of full employment". In M. Kalecki (1971). Selected essays on the dynamics of the capitalist economy. Cambridge: Cambridge University Press.

LAYARD, R. (1982). "Is income policy the answer?". Economica, 49.

ROWTHORN, B. (1977). "Conflict, inflation and money". Cambridge Journal of Economics, 1. SCHOTT, K. (1984). Policy, power and order, New Haven: Yale University Press.

WALLICH, H. \& STOCKTON, D. (1989). "A macroeconomic perspective on tax-based income policies". In J. Kregel (ed.) Inflation and income distribution in capitalist crisis, London: Macmillan. WEINTRAUB, S. \& WALLICH, H. (1971). “A tax-based incomes policy”. In S. Weintraub (ed.). Keynes, Keynesians and Monetarists. Pennsylvania: University of Pennsylvania Press, 1983. 